Volume 7, No. 12 December 2019

International Journal of Emerging Trends in Engineering Research

Available Online at http://www.warse.org/IJETER/static/pdf/file/ijeter117122019.pdf

https://doi.org/10.30534/ijeter/2019/117122019

\title{
Designing Blockchain to Minimize Fraud in State-Owned National Insurance Company (BPJS Kesehatan)
}

\author{
${ }^{1}$ Hendrico Andre, ${ }^{2}$ Ade Kartika Dewi, ${ }^{3}$ Firman Pangemanan, ${ }^{4}$ Gunawan Wang \\ Information Systems Management Department, BINUS Graduate Program - Master Of Information Systems, \\ Bina Nusantara University, Jakarta, Indonesia,11480. E-mail: ${ }^{1}$ andre.hendrico@ binus.ac.id; ${ }^{2}$ ade.dewi001@binus.edu; \\ pangemanan.firman@ binus.ac.id; ${ }^{3}$ gwang @ binus.edu.
}

\begin{abstract}
Health insurance system in Indonesia especially BPJS Kesehatan still have problems and one of it is the possibility of fraud. Fraud in BPJS Kesehatan can be the source of loss if it not anticipated very well. Fraud can happen because of bad registration, no transparency in the data and minimum monitoring from third party outside the insurance components. This research consist of analysis and design of the fraud possibilities can be minimize and anticipated as much as possible. Blockchain is one of alternative method approach that can be applied for this matter because blockchain is good to analyze Big Data. Blockchain registered records by distributions, so that with the good records registration and distributed can minimize the possibility of the fraud. Based on the analysis result, identification and design that been made, proposed several actors, participants also activity process for each actor, business process, data requirement and transaction process that can minimize fraud in BPJS Kesehatan system.
\end{abstract}

Key words: Health Insurance, Fraud, Blockchain, BPJS Kesehatan

\section{INTRODUCTION}

BPJS Kesehatan previously known as Askes (Asuransi Kesehatan), managed by PT Askes Indonesia (Persero), amended as per UU No. 24 Tahun 2011 about BPJS, PT. Askes Indonesia transformed to BPJS Kesehatan since January $1^{\text {st }} 2014$. Every Indonesian citizen dan foreigner that have been worked in Indonesia at least six months are mandatory to registered as BPJS. This is following with pasal 14 UU BPJS. Every corporation mandatory to register their workers as BPJS members. While people or family that not working in a corporation mandatory to register themselves with their family to BPJS [1].

Every BPJS members require to pay a premium with amount to be decided afterwards. For the poor citizen, the premium of BPJS covered by government through Program Bantuan Iuran. Becoming BPJS members not only mandatory for workers from formal sector, but also included to non-formal sector workers. Informal workers also mandatory to become a BPJS Kesehatan member. Workers mandatory to register themselves and pay premium depend on the benefit class wanted.

Health insurance universally expected can be started in stages on 2014 and by 2019 expected all Indonesian citizen already has that health insurance. Health Minister
Nafsiah Mboi stated that BPJS Kesehatan will be managed to cover all illness however with efficiency.

Fraud is an intended misuse action to get benefit for individual or group or other party (individual, corporation or institution) that caused loss or even worse risk. Fraud can be happened due to pressure, opportunity, and excuse to adjust the fraud itself [2].

Up till now BPJS reported loss to amount Rp 28,5 Triliun during 2019 [3]. Registration system that easily manipulated become main problem that caused very highly fraud possibility risk. Data fraud from Hospital parts very much burdened BPJS as patient's guarantor.

Based on above problems, researchers interested to create a blockchain basis system in order to minimize fraud possibility. Blockchain basically a digital registration method, this ledger will be distributed to all participants within blockchain network [4]. Through blockchain approach then every entity within the network will get the accurate and transparent data.

\section{LITERATURE REVIEW}

\section{A. Blockchain}

Blockchain firstly introduced from Bitcoin system, main purpose of bitcoin as an online payment process between one party to another without depending to the intermediary [4]. Blockchain used to register the whole transactions that happened within bitcoin and distribute to all participants involved within blockchain network after consensus process [4]. Consensus is a mechanism used by node within blockchain network to do verification to the ledger that will be distributed [5]. Ledger is a record of the whole transactions data executed [4]. This is a part of distributed database which consist of the transactions that keep in a block data. Each block has their own unique hash that produced depend on the contain of the block itself. Every block saves the hash from other block before that create a chain which keep in each node within peer to peer network.

\section{B. Distributed Database and Decentralized Database}

Distributed database is a storage method where storage device is not attached to a computer, instead several computers. That several computers can be connected to a storage device even several different storage devices that connected through network. This method which make the database transparent to all users [5]. 
Decentralized system is a designed system consist of several computers called nodes within a network and has the authority to configure their own functions to reach goal from the main central system. Every node has their own system and has unique functions to provide contribution to the main system [5].

\section{Fraud}

In principal fraud is an action of deception or cheat to get benefit for the fraudster or their accomplice. Fraud can be initiated from insurance participants, insurance organizers and Healthcare Services. Fraud initiated from healthcare services can be caused because of unsatisfied hospital against INACBG (Indonesia Case Base Groups as an application to submit claim to the government) and unprepared technology of IS/IT in the hospital. Furthermore, motivation to search for economic profit can be one of the causes for healthcare services initiate fraud [6].

Types of fraud focused in this research as follow [7]:

a. Phantom Billing is a false claim for services that never provided.

b. Phantom Procedures is a series activity of a service that never been executed.

c. Phantom Visit is a false patient visit claim.

d. No medical value is a claim of activity that not based on medical necessity.

\section{Hyperledger}

Hyperledger is a collaboration project with opensource method related to blockchain. This project developed to advance blockchain technology for implementation in industry sector. Hyperledger consist of collaboration of banking sector, financial sector, Internet of Things, manufacture, supply chain and technology. Hyperledger function to unite the users, developers and vendors from multi sector and markets [8].

Hyperledger Fabric is a framework to implement a private blockchain, where within a network only enlisted members that can access that very network. Fabric authorized components like consensus and member services to plug and play. This is exploiting the coordinating technology to become host for the smart contracts that called "chain code" that consist of rules of business from system. That thing designed to support many components to become pluggable also provide network security, scalable and confidentiality that ready to use [8].

\section{SYSTEM DESIGN}

\section{E. System Analysis}

Characteristics of the blockchain are very supportive to reach a transparent system and verifiable truth. The system can be composed with the values as follows:

- Transparency. Blockchain is a public ledger, where everyone can see or even multiply the data within blockchain.

- Dependability. Blockchain are blocks that connected with cryptographic technique and has decentralized system in which every block distributed to all nodes.
Therefore, to modify a data in blockchain has a very high level of difficulty and almost not possible to be done. This make all the data entered to the system safely ensured unable to be doubled, modify or deleted.

- Eligibility. Only verified users that has access to do entry data to the system. To add a block in blockchain require a valid and legit transaction. A transaction stated as a valid and legit when there are digital signature on that transactions. And that thing can only be done by a user that has a pair of keys that has been verified by blockchain.

- Verifiability. Blockchain is a public ledger and every transaction made can be acknowledge from the details of that transaction itself.

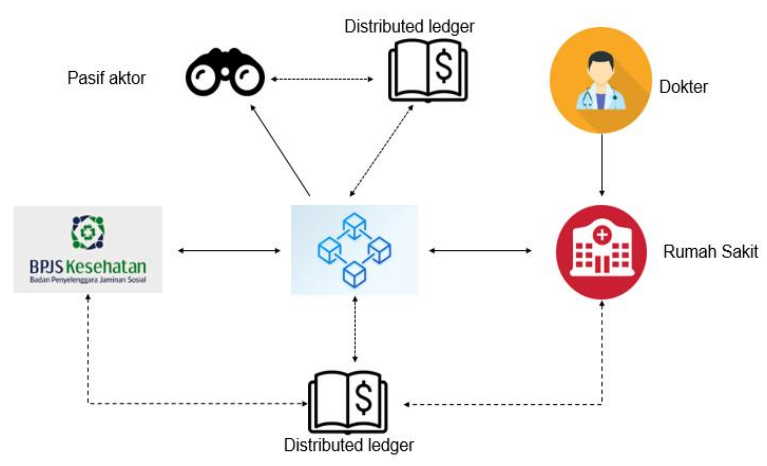

Figure 1: Design System Blockchain.

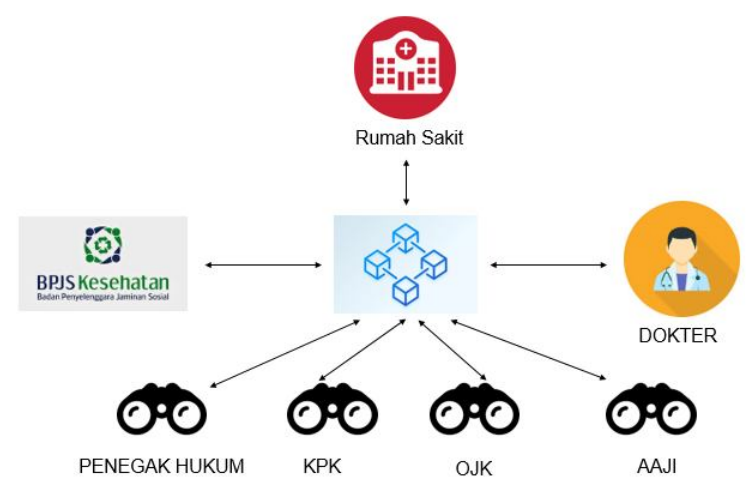

Figure 2: Design System Actor.

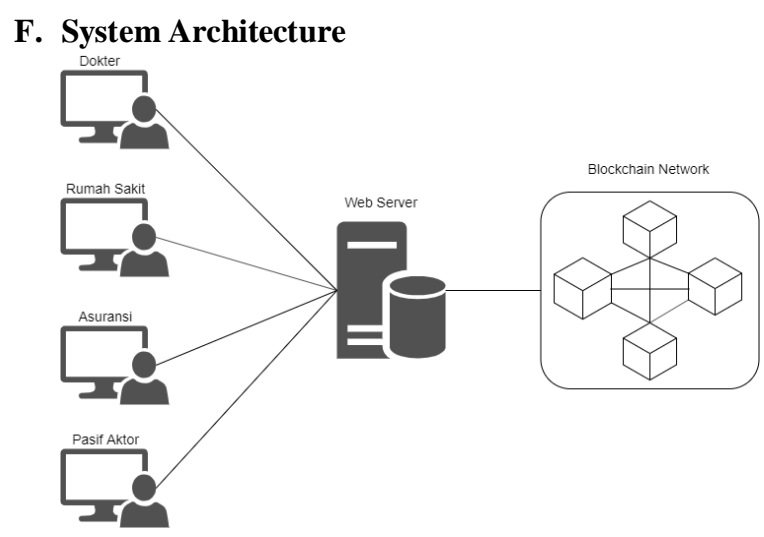

Figure 3: Design System Architecture 
The pictures explain the design system architecture that will be applied such as computer on client section, webserver and blockchain network. Computer client authorized to access webpage of Blockchain Fraud Insurance System Information. Every interaction within the web will go through webserver. Webserver is a centralized based that control all web activities also become a connector with blockchain network. To connect webserver with blockchain node, framework Hyperledger Fabric applied with configuration of access management, transaction functions and queries to be process. Type of the blockchain used is a Permissioned Blockchain which means the blockchain can only be access by members with authorized access and they are the actors involved.

\section{G. Actor Activity Table}

During implementing the system there are activities from each actor as the table below:

Table 1: Activity Table.

\begin{tabular}{|l|l|l|}
\hline No & Actor & Activities \\
\hline 1 & Doctor & $\begin{array}{l}\text {-Input Prescription } \\
\text {-Input Diagnosis } \\
\text {-Input Medical Checkup }\end{array}$ \\
\hline 2 & Hospital & $\begin{array}{l}\text {-Input Medicine Stock } \\
\text {-Input Patient Medical History } \\
\text {-Input Billing Transaction } \\
\text {-Input Claim }\end{array}$ \\
\hline 3 & Insurance & $\begin{array}{l}\text {-Verification Claim } \\
\text {-Approval Claim }\end{array}$ \\
\hline 4 & Passive Actor & -Monitoring \\
\hline
\end{tabular}

\section{H. Transaction Activity}

After identified an activity that will proceed by each actor, the next step for registration claim request process will be explained as table below:

Table 2:Asset List Table

\begin{tabular}{|l|l|l|}
\hline No & Asset Name & Functions \\
\hline 1 & Medicine & $\begin{array}{l}\text { Records medicine data in a } \\
\text { hospital }\end{array}$ \\
\hline 2 & Hospital Bill & $\begin{array}{l}\text { Records the hospital bill issued } \\
\text { for the actual service for patient }\end{array}$ \\
\hline 3 & $\begin{array}{l}\text { Transaction } \\
\text { History }\end{array}$ & $\begin{array}{l}\text { Records every history of claim } \\
\text { transaction from hospital to } \\
\text { insurance }\end{array}$ \\
\hline
\end{tabular}

Afterward the main transaction for claim process by the hospital and claim verification by insurance part shown below:

Table 3:Transaction List Table

\begin{tabular}{|l|l|l|l|}
\hline No & $\begin{array}{l}\text { Transaction } \\
\text { Name }\end{array}$ & Actor & Remarks \\
\hline 1 & $\begin{array}{l}\text { Transaction } \\
\text { Claim }\end{array}$ & Hospital & $\begin{array}{l}\text { To submit the } \\
\text { billing claim with } \\
\text { status Not Paid by } \\
\text { insurance }\end{array}$ \\
\hline 2 & $\begin{array}{l}\text { Verification } \\
\text { Claim }\end{array}$ & Insurance & $\begin{array}{l}\text { To verified billing } \\
\text { claim and do the } \\
\text { payment. }\end{array}$ \\
\hline
\end{tabular}

\section{Activity Diagram}

Next to see the process activity from every actor joined in the system, then the activity diagram can be designed as follows:

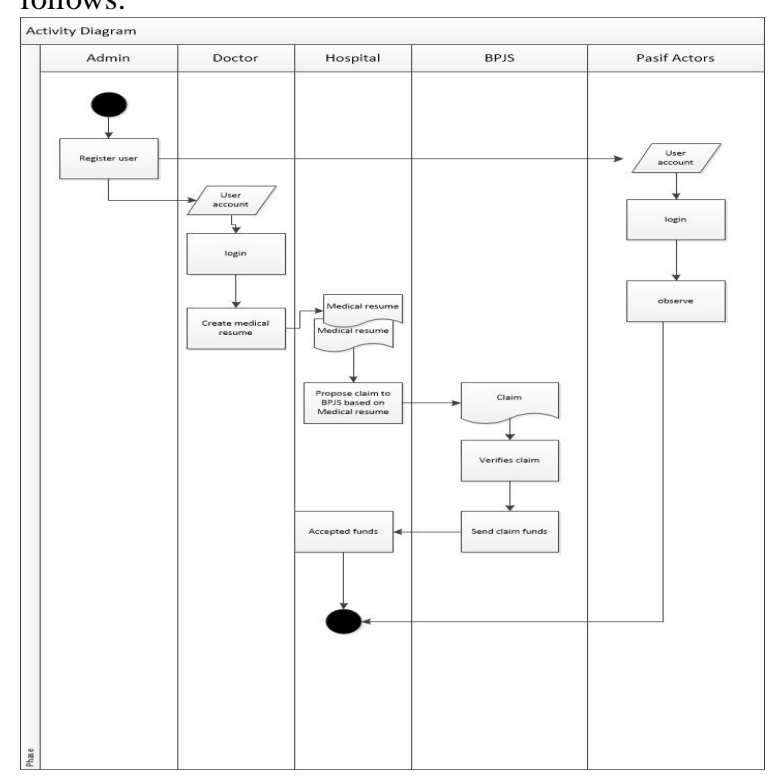

Figure 4:Activity Diagram.

\section{J. Flowchart}

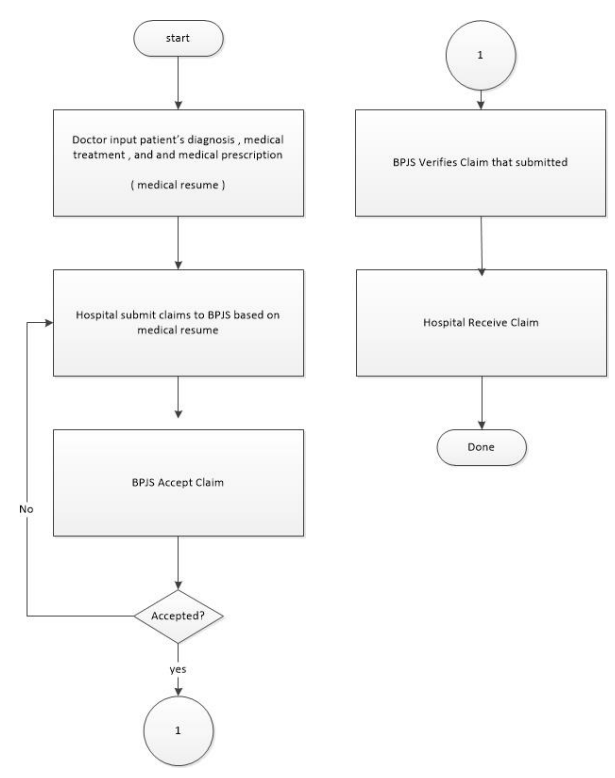

Figure 5: Flowchart.

\section{K. Data Transaction}

Next the transaction data will be distributed to all node or participants that involved in the blockchain system. This is the design of the table data:

Table 4: Design of Data Table

\begin{tabular}{|l|l|l|l|l|}
\hline No & Trx_ID & Actor_ID & Trx_Date & Claim_Status \\
\hline 1 & 20019001 & rs_01 & $20-10-2019$ & approve \\
\hline 2 & 20019002 & rs_01 & $22-10-2019$ & pending \\
\hline 3 & 20019003 & rs_02 & $23-10-2019$ & pending \\
\hline 4 & 20019004 & rs_03 & $22-10-2019$ & approve \\
\hline 5 & 20019005 & rs_02 & $20-10-2019$ & pending \\
\hline
\end{tabular}




\section{CONCLUSION AND SUGGESTION}

This research showing system design to minimize, prevent and anticipate the fraud within health insurance system especially BPJS Kesehatan Insurance by applying the blockchain technology. With system design, architecture design and defining actor role that involved within the system can anticipate fraud. The system designed based on the blockchain method will always do the registration and distribution of the ledger to all blockchain participants. The transaction records that has been made using blockchain principal cannot be alter nor remove. With this, all transactions will fulfill the blockchain principles which are transparent and verifiable.

Research process for this paper can still be develop more to reduce the possibility of fraud in health insurance system such as real-test, new scheme design for the system flowchart and others.

\section{REFERENCES}

[1] Catat! Ini Perbedaan BPJS Kesehatan dan BPJS Ketenagakerjaan,bpjsketenagakerjaan.com,29 April 2019

Dapat diakses pada : https://www.bpjsketenagakerjaan.go.id/berita/25022/C atat!-Ini-Perbedaan-BPJS-Kesehatan-dan-BPJS-

Ketenagakerjaan.

[2] The Chartered Institute of Public Finance \& Accountancy (2010) "Fraud Definition and Examples,"
The Chartered Institute of Public Finanace \& Accountancy, hal. 1-2. Tersedia pada: http://www.cipfa.org/html/elearning/nasbm/fraud awareness/resources/frauddefinitionandexamples.pdf.

[3] Per Oktober 2019, Utang Jatuh Tempo BPJS Kesehatan Rp 21,16 Triliun,kompas.com,6 November 2019.

Dapat diakses pada : https://money.kompas.com $/ \mathrm{read} / 2019 / 11 / 06 / 163100126 /$ per-oktober-2019-utangjatuh-tempo-bpjs-kesehatan-rp-21-16-triliun.

[4] Sehgal, A. (2017) "Blockchain Insurance Business Implementation," 174(3), hal. 32-37.

Tersedia pada: https://www.ijcaonline.org/archives/ volume174/number3/sehgal-2017-ijca915361.pdf. https://doi.org/10.5120/ijca2017915361

[5] Conte de Leon, Daniel \& Q. Stalick, Antonius \& Jillepalli, Ananth \& A. Haney, Michael \& Sheldon, F.T. 2017. Blockchain: properties and misconceptions. Asia Pacific Journal of Innovation and Entrepreneurship. 11: 286-300.

[6] BPJS-Kesehatan (2015) "Peran bpjs kesehatan dalam pencegahan fraud dan abuse dalam system jaminan kesehatan nasional (jkn)," hal. 24. Tersedia pada: http://diskes.jabarprov.go.id/dmdocuments/9b1cfb679 7c4408531082425ae3c60c6.pdf.

[7] Chae, M. dkk. (2007) "An empirical analysis of fraud detection in online auctions: Credit card phantom transaction," Proceedings of the Annual Hawaii International Conference on System Sciences, (April). https://doi.org/10.1109/HICSS.2007.61

[8] Maheshwari, Shikha. (2018): Blockchain basics: Hyperledger Fabric and Hyperledger Composer. 